3. Berrett D. How 'flipping' the classroom can improve the traditional lecture. The Chronicle of Higher Education. 2012. URL: https://www.chronicle.com/article/how-flipping-the-classroom-canimprove-the-traditional-lecture/ (Retrieved 01.02.2021)

4. Brame C. Flipping the classroom. Vanderbilt University Center for Teaching. URL: http://cft.vanderbilt.edu/guides-sub-pages/flipping-theclassroom/ (Retrieved 15.02.2021)

5. Crouch C.H. and Mazur E. Peer instruction: Ten years of experience and results. American Journal of Physics. 2001. № 69. P. 970-977.

6. Lage M.J., Platt G.J. and Treglia M. Inverting the classroom: A gateway to creating an inclusive learning environment. The Journal of Economic Education. 2000. № 31. P. 30-43.

DOI https://doi.org/10.30525/978-9934-26-039-1-90

\title{
TRANSLATION IN LANGUAGE TEACHING AND LEARNING
}

\author{
Babiuk O. V. \\ Candidate of Pedagogical Sciences, \\ English Teacher \\ Halytskyi College named after Viacheslav Chornovil \\ Ternopil, Ukraine
}

Translation played an important role in classical language teaching within Grammar Translation Method. The development of Modern Language teaching approaches led to dominance of more «natural» methods, which underestimated the role of translation in classroom. Translation seemed to be rejected in Communicative Language Teaching both as a teaching and as an assessment tool, and together with explicit grammar teaching was supposed to be an obstacle rather than an effective activity in language acquisition [3].

However, translation gradually regained position in language teaching, which was to much extent due to the development of Translation Studies and changing ideas of Applied Linguistics. Research proved that translation is an unconscious and inevitable element in foreign-language comprehension [6] and that is why there is a solid ground for the «rehabilitation» of the use of translation in language teaching [2] as a key aspect in acquiring the communicative competence [3]. 
There is not any proof that translation influences negatively language learning, and it is highly doubtful that understanding how a language works is an obstacle in its acquisition [2, p.122]. Comparing language students with medical students, Cook claims that the latter undergo a lot of academic study of anatomy, biology etc., which is considered to be a help rather than a barrier in practical medicine [2, p.122]. The same conclusions can be made about learning a language - the better students understand it, the more chances they have to become good language users.

Nowadays Grammar Translation method is viewed differently as it has been recognized that it involved not impractical translation, but thorough analysis and interpretation of texts, focus on grammar and vocabulary; fostered critical thinking and reasoning. It is considered that the main purpose of Grammar Translation Method was not only to foster students' grammar and vocabulary acquisition, but also to learn to appreciate the foreign culture and literature and as a result achieve better understanding of the language [1, p. 12].

Translation as a language-learning activity has been given different names, such as «school translation», «pedagogical translation», «academic translation», «act of translating» [4], the most popular of which is «pedagogical translation». This type of language learning activity is widely used at different levels with different objectives, which proves the validity and relevance of pedagogical translation.

«Pedagogical translation» refers to the use of translation in classroom in various ways, e.g., when translation is produced in a final form to be assessed by the teacher or when it is used to clarify comprehension of the text, often as a group activity. Students acquire language understanding, knowledge and skills through manipulation of texts, observation, «contrastive analysis and conscious reflection» $[3$, p. 121] being involved in problem-solving activities and interesting communication among peers and the teacher [4, p.742].

Now experts realize that pedagogical translation can be a communicative activity [5, p. 80] which includes discussion on the translation (both written and oral), explanation of grammar, analysis of the decontextualized sentences translated by the students, speculation over the possible context in which the decontextualized sentences can be used; peer review of the written translations and their further corrections and improvement. Students can produce their own texts in mother tongue to be translated by their classmates with the particular focus on some vocabulary, structures etc. using all their imagination and creativity. 
Translation can be incorporated in listening comprehension activities when students are asked to translate some parts that can be misunderstood or misinterpreted.

Translation is an effective tool in the development of vocabulary, grammar, reading, writing, listening and speaking skills. Besides, it fosters the development of metalinguistic awareness as translation helps learners to focus more on sentence forms and discourse structures [4, p. 743] while analyzing and discussing the language students are learning [2, p. 143], which is of utmost importance for the development of the ability to see the language as a whole, understand it and control its usage.

Translation should be updated with the help of information technologies, namely specialized software, online platforms. Teachers can effectively incorporate electronic translators in language teaching by asking students to compare their translations with, for example, Google translations, or correcting the text translated by Google translator. The task of the teacher is to teach students to take advantage of electronic translators realizing their limitations.

Translation is and has always been an effective tool in a foreign language acquisition regardless of level of foreign language proficiency.

\section{References}

1. Alcalde Mato N. Principales métodos de enseñanza de lenguas extranjeras en Alemania. Revista de Lingüistica y Lenguas Aplicadas. 2011. № 6. P. 9-23.

2. Cook G. Translation in Language Teaching. Oxford, UK: Oxford University Press, 2010. 202 p.

3. D'Amore A. M. The Role of Translation in Language Teaching: Back to GT in ELT? Handbook of Research on Teaching Methods in Language Translation and Interpretation / Cui Y., Zhao W. (Eds). Information Science Reference (an imprint of IGI Global), 2015. P. 118-136.

4. Machida S. Translation in Teaching a Foreign (Second) Language: A Methodological Perspective. Journal of Language Teaching and Research. 2011. № 2(4). P. 740-746.

5. Randaccio M. Translation and Language Teaching: Translation as a useful teaching Re-source. In F. Gori \& C. Taylor (Eds.). Aspetti della didattica e dell'appredimiento delle lingue straniere: contributi dei collaboratori del Centro Linguistico dell'Università di Trieste. 2012. P. 78-91.

6. Thierry G., Wu Y. J. Brain potentials reveal unconscious translation during foreign-language comprehension. Proceedings of the National Academy of Sciences of the United States of America. 2007. № 104(30). P. 12530-12535. 